\title{
Phytotoxicity of Callistemon viminalis essential oil against some weeds
}

Aditi Shreeya Bali ${ }^{*}$, Daizy R. Batish ${ }^{1}$, Harminder Pal Singh $^{2}$

${ }^{1}$ Department of Botany, ${ }^{2}$ Department of Environment Studies, Panjab University, Chandigarh 160014, India.

Received: October 17, 2016; Accepted: October 28, 2016

\begin{abstract}
The present study investigated the phytotoxic potential of Callistemon viminalis essential oil against some weeds viz. Ageratum conyzoides, Sorghum halepense, Leptochloa chinensis and Commelina benghalensis in order to assess its herbicidal activity. The laboratory bioassay revealed that Callistemon oil (0.025-0.1 \%) decreased the emergence and early growth of test species in a dose-dependent manner. At $0.1 \%$ Callistemon oil treatment none of the seeds of $C$. benghalensis germinated. The Callistemon oil not only affected the germination and early growth of weed species but also severely decreased the chlorophyll content of the test plants. The chlorophyll content decreased by $\sim 71 \%$ in C. benghalensis in response to $0.05 \%$ Callistemon oil treatment. These results strongly indicate the adverse effect of Callistemon oil on photosynthesis of test plants. Based on the study, it can be concluded that Callistemon oil possess phytotoxic potential and can be used as bioherbicide in weed management programmes.
\end{abstract}

Key words: Allelochemicals; Bioherbicide; Phytotoxicity; Weed management

\section{Introduction}

Weeds are generally referred to as unwanted plants that grow at places where not required and interfere with the growth and establishment of other useful plants. In India, Varshney and Prasad Babu (2008) reported $15-85 \%$ crop loss due to interference of weeds with crops. They serve as host for many plant diseases and pests and also adversely affect human health (Mazza et al., 2014). Various mechanical, biological and chemical methods are applied for controlling weeds. Of these, mechanical and biological methods fail to provide adequate weed control and thus chemical methods are used worldwide. In fact, modern agriculture is largely based on the use of synthetic herbicides for controlling weeds obviously because their action is fast and mode of application comparatively easier. Unfortunately, during the last 20-30 years it is being realized that indiscriminate use of synthetic herbicides for controlling weeds has not only deteriorated the environment quality but has also led to development of herbicidal resistance among weeds. Due to this, efforts are being made towards the search for new / novel technologies and cultural practices for managing weeds to sustain continued crop yield (Dayan and Duke, 2014). Nowadays, natural plant products are receiving attention of plant researchers as potential bioherbicides for weed management owing to their allelopathic properties. It is primarily because these plants based products are environmentally safer, biodegradable, possesses low mammalian toxicity than the synthetic herbicides which are expensive too (Dayan et al., 2012).

\section{*Corresponding Author:}

\section{Aditi Shreeya Bali}

Department of Botany,

Panjab University,

Chandigarh 160014, India.

E- mail: shreeyaaditi02@gmail.com
Among different natural plant products, allelochemicals (chemicals responsible for allelopathy) are being explored as an important tool in weed management because of their structural and chemical diversity (Singh et al., 2003). Among allelochemicals, volatile essential oils and their constituent monoterpenes are known to possess very high phytotoxicity towards a number of other plants (Muller and Muller, 1964; Singh et al., 2009). Essential oils are complex mixture of mono $\left(\mathrm{C}_{10}\right)$ and sesquiterpenes hydrocarbons $\left(\mathrm{C}_{15}\right)$ along with alcohols, esters, aldehydes and ketones that determine characteristic color and odor of the donor plant. They are also used in pharmaceutical, food, cosmetic and perfume industry (Batish et al., 2008).

C. viminalis (Gaertn.) G. Don., commonly known as weeping bottlebrush, is one of the very common species of Callistemon, extensively cultivated in the gardens, parks and road sides in different parts of the world including India (Anonymous, 1992). It has pendulous evergreen foliage with crimson red flowers. Besides, the tree is aromatic particularly its leaves and inflorescence. According to Garg and Kasera (1982), oil from C. viminalis exhibited anthelmintic activity against tapeworm and hookworm. The essential oil obtained from $C$. viminalis also exhibited antibacterial and antioxidant, and insecticidal activities. Owing to their selective phytotoxic effects and biodegradable nature, essential oil extracted from $C$. viminalis containing a mixture of monoterpenes offer a great deal of 
promise for future to serve as novel herbicides. Though the phytotoxic effect of compounds extracted from $C$. citrinus has been studied, yet studies pertaining to phytotoxic effect of $C$. viminalis essential oil are lacking. de Oliveira et al., (2014) reported that essential oil extracted from the flowers of $C$. viminalis possess allelopathic properties. However, nothing is known about the phytotoxicity of essential oil of $C$. viminalis. Since only a few weeds grow under $C$. viminalis, it was hypothesized that plant may inhibit the growth of under-storey or nearby plants due to the release of foliar volatiles from its foliage.

\section{Materials and Methods}

Collection of plant material: Mature leaves from trees of C. viminalis were collected from Panjab University campus, Chandigarh, India. The material was collected in early hours to obtain maximum quantity of oil possible.

Extraction of oil: Volatile essential oil was extracted from leaves of $C$. viminalis by hydrodistillation using Clevenger's apparatus. For this $2 \mathrm{~kg}$ of freshly collected material was chopped into pieces and mixed with $1 \mathrm{~L}$ of distilled water in a container of Clevenger's apparatus fitted with a condenser. Leaves were boiled for $5 \mathrm{~h}$ and after cooling, oil was collected from the nozzle. The oil thus obtained was dried over anhydrous sodium sulphate and stored at $4{ }^{\circ} \mathrm{C}$ for further use.

Collection of seeds: Seeds of various weeds like Johnson grass (Sorghum halepense (L.) Pers), benghal dayflower (Commelina benghalensis L.) and billygoat weed (Ageratum conyzoides L.) were collected from wildly growing stands in Panjab University campus, Chandigarh whereas seeds of chinese sprangletop (Leptochloa chinensis (L.) Nees were collected from the agricultural fields in and around Chandigarh. These were selected because they are troublesome, economically important and are common in this region.

Growth bioassay with Callistemon oil in solution form: Uniform, healthy and viable seeds of test weeds were surface sterilized with $2 \%$ sodium hypochlorite for 1-2 $\mathrm{min}$ before imbibitions. For solution form, various concentrations $(0.025,0.05,0.1 \%)$ of oil were prepared by dissolving oil in distilled water with the help of Tween-20. Petri dishes $(15 \mathrm{~cm})$ were lined with two layers of Whatman No. 1 filter paper and moistened with $10 \mathrm{ml}$ of various oil concentrations as per the method of Batish et al., (2004).

After 7 days, number of seeds germinated was counted in each Petri dish. Plant growth (in terms of root and shoot length) was measured with the help of scale. Leaves of test plants were taken for further determination of chlorophyll content.

Total Chlorophyll Content: Total chlorophyll content from leaves of test plants (both control and treated) was extracted in dimethyl sulphoxide (DMSO) following the method of Hiscox and Israelstam (1979). The extinction value was measured at dual wavelength of 645 and $663 \mathrm{~nm}$ on Shimadzu UV-1800 double beam spectrophotometer using DMSO as blank. Total chlorophyll content was calculated from extinction values following Arnon`s equation (1949) and was expressed on dry weight basis, as suggested by Rani and Kohli (1991).

Statistical analysis: The statistical analysis of data was done using one-way ANOVA followed by the comparison of mean values using post hoc Tukey's test at $P \leq 0.05$ and finally presented as mean \pm SE (Standard Error) using software program SPSS (Version 16.0).

\section{Results and Discussion}

Callistemon oil reduced the germination of test plants in a concentration-dependent manner. At lower concentrations $(0.025 \%)$ of oil, very less difference in germination of treated seeds vir. A. conyzoides $(\sim 12 \%)$, S. halepense $(\sim 12 \%)$ over control was observed, however, in $L$. chinensis $(\sim 44 \%)$ and $C$. benghalensis $(\sim 44 \%)$, the germination decreased significantly $(P \leq 0.05)$ compared to control (Table 1). Among the test species studied, $C$. benghalensis showed $100 \%$ inhibition in germination at $0.1 \%$ concentration of Callistemon oil (Table 1). At $0.1 \%$ Callistemon oil treatment, $\sim 44 \%, \sim 45 \%$ and $\sim 94 \%$ inhibition in germination was observed in $A$. conyzoides, $S$. halepense and $L$. chinensis over the control (Table 1).

Table 1: Effect of Callistemon oil on germination (\%) of test weeds

\begin{tabular}{lllll}
\hline Conc. (\%) & Ageratum conyzoides & Sorghum halepense & Leptochloa chinensis & Commelina benghalensis \\
\hline 0 & $98.3 \pm 1.67 \mathrm{a}(0)$ & $81.7 \pm 4.41 \mathrm{a}(0)$ & $80.0 \pm 5.77 \mathrm{a}(0)$ & $95.6 \pm 2.22 \mathrm{a}(0)$ \\
0.025 & $86.7 \pm 1.67 \mathrm{~b}(11.8)$ & $71.7 \pm 1.67 \mathrm{a}(12.2)$ & $45.0 \pm 2.89 \mathrm{~b}(43.8)$ & $53.3 \pm 10.18 \mathrm{~b}(44.3)$ \\
0.05 & $70.0 \pm 2.87 \mathrm{c}(28.8)$ & $55.0 \pm 2.89 \mathrm{~b}(32.7)$ & $28.3 \pm 3.33 \mathrm{c}(64.6)$ & $26.7 \pm 10.18 \mathrm{c}(72.1)$ \\
0.1 & $55.0 \pm 2.87 \mathrm{~d}(44.1)$ & $45.0 \pm 2.89 \mathrm{~b}(44.9)$ & $5.0 \pm 2.89 \mathrm{~d}(93.8)$ & - \\
\hline
\end{tabular}

Data presented as mean \pm SE.

Different alphabets represent significant difference at $P \leq 0.05$ after applying post hoc Tukey's test.

Values within parenthesis indicate percent decrease over control. 
Table 2: Effect of Callistemon oil on root length (cm) of test weeds

\begin{tabular}{ccccc}
\hline Conc. (\%) & Ageratum conyzoides & Sorghum halepense & Leptochloa chinensis & Commelina benghalensis \\
\hline 0 & $0.9 \pm 0.01 \mathrm{a}(0)$ & $5.8 \pm 0.03 \mathrm{a}(0)$ & $3.9 \pm 0.06 \mathrm{a}(0)$ & $4.7 \pm 0.04 \mathrm{a}(0)$ \\
0.025 & $0.6 \pm 0.03 \mathrm{c}(33.3)$ & $5.1 \pm 0.02 \mathrm{~b}(12.1)$ & $2.4 \pm 0.05 \mathrm{~b}(38.5)$ & $3.2 \pm 0.03 \mathrm{~b}(31.9)$ \\
0.05 & $0.5 \pm 0.01 \mathrm{~d}(44.4)$ & $4.7 \pm 0.01 \mathrm{c}(19.0)$ & $2.0 \pm 0.04 \mathrm{c}(48.7)$ & $2.2 \pm 0.04 \mathrm{c}(53.2)$ \\
0.1 & $0.3 \pm 0.01 \mathrm{e}(66.7)$ & $4.3 \pm 0.03 \mathrm{~d}(25.9)$ & $0.6 \pm 0.04 \mathrm{~d}(84.6)$ & - \\
\hline
\end{tabular}

Data presented as mean \pm SE.

Different alphabets represent significant difference at $P \leq 0.05$ after applying post hoc Tukey's test.

Values within parenthesis indicate percent decrease over control.

Table 3: Effect of Callistemon oil on shoot length (cm) of test weeds

\begin{tabular}{ccccc}
\hline Conc. (\%) & Ageratum conyzoides & Sorghum halepense & Leptochloa chinensis & Commelina benghalensis \\
\hline 0 & $1.4 \pm 0.01 \mathrm{a}(0)$ & $8.2 \pm 0.03 \mathrm{a}(0)$ & $6.2 \pm 0.04 \mathrm{a}(0)$ & $3.4 \pm 0.02 \mathrm{a}(0)$ \\
0.025 & $1.0 \pm 0.02 \mathrm{~b}(28.6)$ & $7.1 \pm 0.03 \mathrm{~b}(13.4)$ & $4.6 \pm 0.04 \mathrm{~b}(25.8)$ & $2.2 \pm 0.03 \mathrm{~b}(35.3)$ \\
0.05 & $0.8 \pm 0.04 \mathrm{c}(42.9)$ & $6.5 \pm 0.02 \mathrm{c}(20.7)$ & $3.3 \pm 0.02 \mathrm{c}(46.8)$ & $1.8 \pm 0.05 \mathrm{c}(47.1)$ \\
0.1 & $0.6 \pm 0.01 \mathrm{~d}(57.1)$ & $4.8 \pm 0.03 \mathrm{~d}(41.5)$ & $1.0 \pm 0.02 \mathrm{~d}(83.9)$ & - \\
\hline
\end{tabular}

Data presented as mean \pm SE.

Different alphabets represent significant difference at $P \leq 0.05$ after applying post hoc Tukey's test.

Values within parenthesis indicate percent decrease over control.

Table 4: Effect of Callistemon oil on chlorophyll content ( $\mu \mathrm{g} / \mathrm{mg} \mathrm{DW})$ of test weeds

\begin{tabular}{ccccc}
\hline Conc. (\%) & Ageratum conyzoides & Sorghum halepense & Leptochloa chinensis & Commelina benghalensis \\
\hline 0 & $9.4 \pm 0.08 \mathrm{a}(0)$ & $7.5 \pm 0.05 \mathrm{a}(0)$ & $10.0 \pm 0.03 \mathrm{a}(0)$ & $10.6 \pm 0.25 \mathrm{a}(0)$ \\
0.025 & $8.3 \pm 0.03 \mathrm{~b}(11.7)$ & $6.7 \pm 0.06 \mathrm{~b}(10.7)$ & $8.0 \pm 0.03 \mathrm{~b}(20.0)$ & $6.0 \pm 0.14 \mathrm{~b}(43.4)$ \\
0.05 & $7.6 \pm 0.10 \mathrm{c}(19.2)$ & $6.5 \pm 0.03 \mathrm{c}(13.3)$ & $8.1 \pm 0.06 \mathrm{~b}(19.0)$ & $3.1 \pm 0.13 \mathrm{c}(70.8)$ \\
0.1 & $5.5 \pm 0.06 \mathrm{~d}(41.5)$ & $5.7 \pm 0.06 \mathrm{~d}(24.0)$ & $5.4 \pm 0.12 \mathrm{c}(46.0)$ & - \\
\hline
\end{tabular}

Data presented as mean \pm SE.

Different alphabets represent significant difference at $P \leq 0.05$ after applying post hoc Tukey's test.

Values within parenthesis indicate percent decrease over control.

Further, the treatment of $0.025 \%$ Callistemon oil reduced the root length by $\sim 33 \%, 12 \%, 39 \%$ and $~$ $32 \%$ in $A$. conyroides, S. halepense, L. Chinensis, $C$. benghalensis, respectively over the control (Table 2). In response to $0.1 \%$ Callistemon oil, $\sim 67 \%, \sim 26 \%$ and $\sim 85 \%$ and $100 \%$ reduction in root length was recorded in $A$. conyzoides, $S$. halepense, $L$. chinensis and C. benghalensis, respectively, compared to the control (Table 2). In general, the shoot length of all the test plants decreased with increase in concentration of oil. In control seedlings of $A$. conyzoides, $S$. halepense, $L$. chinensis and $C$. benghalensis, the coleoptile length was $1.4 \pm 0.01,8.2 \pm 0.03,6.2 \pm 0.04$ and $3.4 \pm 0.02 \mathrm{~cm}$, respectively. Treatment of $0.025 \%$ oil reduced the shoot length by $\sim 29 \%, \sim 13 \%, \sim 26 \%$ and $\sim 35 \%$ in $A$. conyroides, $S$. halepense, $L$. chinensis and $C$. benghalensis, respectively, compared to control (Table 3). At $0.1 \%$ oil treatment, $A$. conyzoides, $S$. balepense, L. chinensis and $C$. benghalensis showed $\sim 57 \%$, $42 \%, \sim 84 \%$ and $100 \%$ inhibition in shoot length.

The growth retardatory effects of Callistemon oil on the test plants is in agreement with earlier studies reporting inhibitory effect of volatile oils from aromatic plants on germination and growth of weeds (Singh et al., 2009; Rolli et al., 2014). Recently, Ghnaya et al., (2016) investigated the herbicidal activity of Tetraclinis articulata (Vahl) Mast. essential oil on Sinapis arvensis L. and Phalaris canariensis L. The results indicated complete inhibition of germination in $S$. arvensis at $4 \mu \mathrm{l} / \mathrm{ml}$ concentration of oil (Ghnaya et al., 2016). The exact mechanism for the reduced germination and early growth of weeds is not known but it could be due to the inhibitory effect of volatiles on the cell division and DNA synthesis of growing root tips (Romagni et al.,
2000; Nishida et al., 2005). The effect of Callistemon oil was more on root growth as compared to shoot growth which might be attributed to the effect of volatile oils on proliferation of root apical meristem cells (Singh et al., 2006) that results in various physiological changes in the plant. The observed inhibitory activity of essential oils in the study may be attributed to the synergistic effect of the constituents in Callistemon oil.

Further, the chlorophyll content declined upon exposure to different concentrations of Callistemon oil. At $0.1 \%$ of oil, the chlorophyll content decreased by $\sim 42 \%, \sim 24 \%, 46 \%$ and $100 \%$ compared to the control, in $A$. conyzoides, S. balepense, L. Chinensis and C. benghalensis (Table 4). Among the weeds, $C$. benghalensis was the most affected one, followed by $L$. chinensis, $A$. conyroides and $S$. balepense. These observations are in conformity with earlier reports that volatiles reduce photosynthetic pigments and thus affect the photosynthetic activity in the plants (Batish et al., 2004; Kaur et al., 2010). However, whether the observed reduction in chlorophyll content was due to decreased synthesis or enhanced degradation of chlorophyll is not known (Yang et al., 2002).

\section{Conclusions}

The present study therefore concludes that Callistemon oil inhibit germination and early growth of weeds by altering the photosynthetic and respiratory metabolism of plants and therefore holds good potential to be used as bioherbicide in the future. 


\section{Acknowledgement}

Aditi Shreeya Bali is thankful to the Department of Science and Technology, New Delhi, India, for financial support in the form of INSPIRE Fellowship.

\section{References}

1. Varshney, JG and MBB Prasad Babu. "Future scenario of weed management in India." Indian Journal of Weed Science 40 (2008): 1-9. Print.

2. Mazza, G, E Tricarico, P Genovesi, and F Gherardi. "Biological invaders are threats to human health: an overview." Ethology Ecology \& Evolution 26 (2014): 112 129. Print.

3. Dayan, FE, and SO Duke. "Natural compounds as next generation herbicides." Plant Physiology 166 (2014): 1090-1105. Print.

4. Dayan, FE, DK Owens, and SO Duke. "Rationale for a natural products approach to herbicide discovery." Pest management science 68 (2012): 519-528. Print.

5. Singh, HP, DR Batish, and RK Kohli. "Allelopathic interactions and allelochemicals: new possibilities for sustainable weed management." Critical reviews in plant sciences 22 (2003): 239-311. Print.

6. Muller, WH, and $\mathrm{CH}$ Muller. "Volatile growth inhibitors produced by Salvia species." Bulletin of the Torrey Botanical Club 91 (1964): 327-330. Print.

7. Singh, HP, S Kaur, S Mittal, DR Batish, and RK Kohli. "Essential oil of Artemisia scoparia inhibits plant growth by generating reactive oxygen species and causing oxidative damage." Journal of chemical ecology 35 (2009): 154-162. Print.

8. Batish, DR, HP Singh, RK Kohli, and S Kaur. "Eucalyptus essential oil as a natural pesticide." Forest Ecology and Management 256 (2008): 2166-2174. Print.

9. Anonymous. "The Wealth of India." Raw Materials. Publications and Information Directorate, CSIR: New Delhi 3 (1992): 63-66. Print.

10. Garg, SC, and HL Kasera. "Anthelmintic activity of Callistemon viminalis." Fitoterapia 53 (1982): 179-181. Print.

11. de Oliveira, CM, M das Graças Cardoso, AC da Silva Figueiredo, MLM de Carvalho, CASF de Miranda, LRM Albuquerque, DL Nelson, M de Souza Gomes, LF Silva, J de Andrade Santiago, and ML Teixeira. "Chemical Composition and Allelopathic Activity of the Essential Oil from Callistemon viminalis (Myrtaceae) Blossoms on Lettuce (Lactuca sativa L.) Seedlings." American Journal of Plant Sciences 5 (2014): 3551-3557. Print.
12. Batish, DR, N Setia, HP Singh, and RK Kohli. "Phytotoxicity of lemon-scented eucalypt oil and its potential use as a bioherbicide." Crop Protection 23 (2004): 1209-1214. Print.

13. Hiscox, JD, and GF Israelstam. "A method for extraction of chlorophyll from leaf tissue without maceration." Canadian Journal of Botany 57 (1979): 1332 1334. Print.

14. Arnon, DI. "Copper enzymes in isolated chloroplasts: polyphenylperoxidase in Beta vulgaris." Plant Physiology 24 (1949): 1-15. Print.

15. Rani, D, and RK Kohli. "Fresh matter is not an appropriate relation unit for chlorophyll content: experience from experiments on effects of herbicides and allelopathic substances." Photosynthetica 25 (1991): 655-657. Print.

16. Rolli, E, M Marieschi, S Maietti, G Sacchetti, and R Bruni. "Comparative phytotoxicity of 25 essential oils on pre-and post-emergence development of Solanum bycopersicum L.: A multivariate approach." Industrial Crops and Products 60 (2014): 280-290. Print.

17. Ghnaya, AB, I Amri, M Hanana, S Gargouri, B Jamoussi, A Romane, and L Hamrouni. "Tetraclinis articulata (Vahl.) Masters essential oil from Tunisia: Chemical characterization and herbicidal and antifungal activities assessment." Industrial Crops and Products 83 (2016): 113-117. Print.

18. Romagni, JG, SN Allen, and FE Dayan. "Allelopathic effects of volatile cineoles on two weedy plant species." Journal of Chemical Ecology 26 (2000): 303-313. Print.

19. Nishida, N, S Tamotsu, N Nagata, C Saito, and A Sakai. "Allelopathic effects of volatile monoterpenoids produced by Salvia leucophylla: inhibition of cell proliferation and DNA synthesis in the root apical meristem of Brassica campestris seedlings." Journal of chemical ecology 31 (2005): 1187-1203. Print.

20. Singh, HP, DR Batish, S Kaur, K Arora, and RK Kohli. " $\alpha$-Pinene inhibits growth and induces oxidative stress in roots." Annals of Botany 98 (2006): 1261-1269. Print.

21. Kaur, S, HP Singh, S Mittal, DR Batish, and RK Kohli. "Phytotoxic effects of volatile oil from Artemisia scoparia against weeds and its possible use as a bioherbicide."00 Industrial Crops and Products 32 (2010): 54-61. Print.

22. Yang, CM, CN Lee, and CH Chou. "Effects of three allelopathic phenolics on chlorophyll accumulation of rice (Oryza sativa) seedlings: I. Inhibition of supplyorientation." Botanical Bulletin of Academia Sinica 43 (2002): 299-304. Print.

Cite this article as:

Aditi Shreeya Bali, Daizy R. Batish, Harminder Pal Singh. Phytotoxicity of Callistemon viminalis essential oil against some weeds. Annals of Plant Sciences 5.10 (2016): 1442-1445.

DOI: http://dx.doi.org/10.21746/aps.2016.10.004

Source of support: Department of Science and Technology, New Delhi, India.

Conflict of interest: None Declared 